\title{
ЛЕКСЕМА КОЗОДОЙ НА ОБЩЕРУССКОМ И СЛАВЯНСКОМ ФOHE
}

\section{Lexeme "Nightjar" on the All-Russian and Slavic Background}

Keywords: ornithonym, lexeme, Slavic languages, dialect, lexicographic description

Contact: МГОУ; k79266644096k@yandex.ru

Большой интерес для исследования представляют наименования птиц, данные им в разных языках. Существует большое количество работ, посвященных изучению орнитонимов в различных аспектах. Исследованием орнитонимических лексем, в аспекте лексикографического представления, занимались Л. В. Амелина, рассматривавшая проблему многозначности орнитонимов русского и немецкого языков, Н. А. Курашкина, Е. И. Зиновьева, писавшая о культурной значимости орнитонима, и другие (Амелина 2010; Курашкина 2015; Зиновьева 2016). Принцип сравнения орнитонимов русского и английского языков отражен в работе Н. Ю. Костиной, русского и испанского - в статье А. П. Денисовой и М. В. Кутьевой, русского и немецкого языков - у Л. В. Тризиной (Костина 2004; Денисова, Кутьева 2010; Тризина 2009). Данная работа является результатом исследований, проведенных Лабораторией палеолингвистики и региональной лексикографии под руководством А. В. Войтенко.

В русском языке содержатся исконные наименования птиц, которые представлены индоевропейскими, общеславянскими, восточнославянскими и собственно русскими словами, а также орнитонимы, заимствованные из разных языков: германских, романских, балтийских, славянских и тюркских.

Целью данной статьи является представление лексико-семантического поля лексемы козодой для дальнейшего анализа истории орнитонима в русском языке, его семантики и сочетаемости. Лексема была исследована на основе материалов этимологических, толковых, исторических и диалектных словарей, а также при помощи данных Национального корпуса русского языка. 
На основе русского и других славянских языков можно составить лексикосемантическое поле (ЛСП) орнитонимической лексемы козодой. Ядерной лексемой ЛСП является общеупотребительная лексема козодой, в центре ЛСП полуночник, лелек, на периферии - наименования козодоя в русском и других славянских языках: ночная ластовица, ночной ворон, кваква, ночная цапля, серая сова, малая сова, летучая мышь, ястреб.

Лексема козодой восходит к латинскому Caprimulgus Europaeus. В «Словаре Академии Российской» приводится наиболее полное толкование лексической единицы. Так, козодой - 'Caprimulgus Europaeus. Птица по предубеждению так названная; иначе известна она под именами Лелек и Полунощник. Сверху покрыта перьями, испещренными поперечными волнистыми серыми и черными черточками; причём каждое перо имеет вдоль проведенную черную полосу; снизу бело-рыжеватыми с поперечными темными чертами; по обеим сторонам клюва, вдоль нижней челюсти, протянута белая полоса; верхней челюсти края окружены жесткими щетинами черноватыми, вперёд загнутыми; пасть обширная; клюв черный; ноги же темного цвета. Питается насекомыми и семенами произрастений; летает только по ночам' (Словарь Академии Российской 1792: 692). В «Русском семантическом словаре» под ред. Н. Ю. Шведовой представлено предположение, что орнитоним заимствован из польского языка, в котором калька с латинского - capri-mulgus (<capra + mulgeo) ‘доящий коз, козодой’ (Русский семантический словарь 1998).

В диалектных словарях наряду с общеупотребительным козодой бытуют разнообразные наименования этой птицы. В вятских говорах на месте данного орнитонима выступает лексема лежень (ОСВГ 2008: 180). В говорах псковских лексема ночвик в своем основном значении - 'птица козодой' (ПОС 2009: 442). «Смоленский областной словарь» содержит следующие данные о рассматриваемом орнитониме: леженька - 'козодой, ночная ласточка' (СОС 1914: 327). В «Толковом словаре живого великорусского языка» В. И. Даля представлены такие дефиниции лексической единицы: козодой - 'птица лилокъ, чурилка, лелек, ночник, полуночник, Caprimulgus europaeus - по перу, это сова, на стати, ласточка' (Даль 1865: 744). Крыластик - 'летучее животное с большими крыльями. Ласточка, козодой и чайки крыластики' (Даль 1865: 811). Также лексемы ночник и ночница употребляются в значении 'ночная птица вообще, сова, козодой' (Даль 1865: 1140).

Эта птица также известна как полуночник и входит в синонимические связи с лексемой козодой. Такое название получила, вероятно, из-за проявления активности преимущественно в ночное время. Полуночник - 'Caprimulgus 
Europaeus, птица. Ночной ворон. Лилок. Козодой' (Словарь церковно-славянского языка 1847: 320). Полуночник - 'Птица. Иначе Ночная ластовица, Козодой' (Словарь Академии Российской 1789-1794: 692).

Лексема полуночник имеет следующие определения в диалектных словарях русского языка: ‘ночной ястребок' (КЯОС 1962: 125), ‘летучая мышь' (СРГСУ 1996: 85).

Наименее употребительной является лексема лелек. Она имеет фонематические варианты: лилек, лилок, лилик. В Этимологическом словаре славянских языков О.Н. Трубачева представлены дефиниции данной лексемы в разных славянских языках. Так, лелек - ст.-чеш. lelek 'кваква; козодой' (Gebauer 1916: 225), в чешском языке определяется как 'ночной ворон; ночная цапля; козодой, ночная ласточка Caprimulgus europaeus’ (Kott 1878-1893: 894). В словацком языке лелек - 'вид ночной птицы, похожей на ласточку, козодой обыкновенный' (SSJ 1959-1968: 29). В старо-польском - 'вид совы, филин-пугач; козодой; ночная цапля; один из видов чаек’ (SStp 1953: 19). В польском же лелек - 'серая сова; птица из семейства Caprimulgidae' (SJP 1900: 713), (ЭССЯ 1987: $105)$.

Также в данном словаре приводятся теории образования лексемы. Ряд исследователей относит к праславянскому *lelěti, lelějati, считая, что птица так названа по характерному для нее качающемуся полету. Иначе, как звукоподражание, трактуется Шафариком (Machek 1957: 326): сербохорв. Lelekati ‘жаловаться, стонать' (птица названа по печальному, ворчливому крику) (ЭССЯ 1987: 105).

Таким образом было проведено наблюдение над данными славянских языков, а также диалектными данными русского языка о многообразии наименований птицы козодой. Данная работа может представлять научный интерес для дальнейшего исследования орнитонимической лексемы.

\section{Summary}

As the title implies the paper describes the history of the ornithonymic lexeme in Slavic languages, as well as its existence in dialects of the Russian language. Some works on the study of ornithonitonyms are mentioned. The lexicographic data of the explanatory, historical, etymological and dialect dictionaries are described in detail. A comparison of synonymous lexeme of Russian and other Slavic languages is given. 


\section{Литература}

Амелина, Л. В. Многозначность и омонимия в системе орнитонимов русского и немецкого языков. Вестник БГУ. 2010 (2). Режим доступа: https://cyberleninka.ru/article/n/mnogoznachnost-i-omonimiya-v-sistemeornitonimov-russkogo-i-nemetskogo-yazykov (2020-04-20).

Даль, В. И. Толковый словарь живого великорусского языка: $B$ ч. СанктПетербург, 1863-1866. Режим доступа: http://slovardalja.net/ (2020-04-20).

Денисова, А. П., Кутьева, М. В. Противоречивость коннотативного потенциала орнитонима paloma/голубь в испанском и русском языках. Вестник РУДН. Серия: Лингвистика. 2010 (4). Режим доступа: https://cyberleninka.ru/ article/n/protivorechivost-konnotativnogo-potentsiala-ornitonima-palomagolub-v-ispanskom-i-russkom-yazykah (2020-04-20).

Добровольский, В. Н. Смоленский областной словарь. Смоленск, 1914. Режим доступа: https://rusneb.ru/catalog/000202_000006_2585465/(2020-04-20).

Зиновьева, Е. И. Культурная значимость орнитонима в аспекте лексикографического представления. Научный диалог. 2016 (50/2). Режим доступа: https://cyberleninka.ru/article/n/kulturnaya-znachimost-ornitonima-vaspekte-leksikograficheskogo-predstavleniya (2020-04-20).

Курашкина, Н. А. Проблема лексикографического описания орнитонимов (на примере названий воробьеобразных птиц). Acta Linguistica Petropolitana. Труды института лингвистических исследований. 2015 (1). Режим доступа: https://cyberleninka.ru/article/n/problema-leksikograficheskogo-opisaniyaornitonimov-na-primere-nazvaniy-vorobieobraznyh-ptits (2020-04-20).

Матвеев, А. К. Словарь русских говоров Среднего Урала. Екатеринбург: Издательство Уральского университета, 1996. Режим доступа: http://elar.urfu.ru/handle/10995/23481 (2020-04-20).

Мельниченко, Г. Г. Краткий ярославский областной словарь, объединяющий материаль ранее составленных словарей: (1820-1956). Ярославль, 1962. Режим доступа: https://www.prlib.ru/item/341397 (2020-04-20).

Псковский областной словарь с историческими данными. Выпуск 21 (Наяви Ночной). Санкт-Петербург: СПбГУ, 2009. Режим доступа: http://www.slovorod.ru/dia-pskov/index.html (2020-04-20).

Словарь Академии Российской. Часть 3 (3-Л). Санкт-Петербург, 1789-1794. Режим доступа: http://etymolog.ruslang.ru/doc/SAR3_Z-M.pdf (2020-04-20). 
Словарь иерковно-славянского и русского языка. Том 3 (O-П). Санкт-Петербург: Императорская Академия Наук, 1847. Режим доступа: http://elib.shpl.ru/ru/ nodes/8463-t-1-a-zh-1847\#mode/inspect/page/70/zoom/4 (2020-04-24).

Сметанина, 3. В. (ред.) Областной словарь вятских говоров. Выпуск 5 (К-Л). Киров: ВятГГУ, 2008. Режим доступа: https://www.studmed.ru/smetanina-zv-red-oblastnoy-slovar-vyatskih-govorov-vypusk-5-k-1_d23aa4fb5ff.html (2020-04-20).

Толстой, Н. И. (общ. ред.) Славянские древности: Этнолингвистический словарь: В 5 m. Москва: Международные отношения, 2012.

Тризна, Л. В. Мотивация именования птиц в русском и немецком языках. Русистика. 2009 (1). Режим доступа: https://cyberleninka.ru/article/n/ motivatsiya-imenovaniya-ptits-v-russkom-i-nemetskom-yazykah (2020-04-20).

Трубачев, О. Н. (ред.) Этимологический словарь славянских языков. Праславянский лексический фонд. Выпуск 14. Москва: Наука, 1987. Режим доступа: http://etymolog.ruslang. ru/index.php?act=essja (2020-04-20).

Шведова, Н. Ю. (общ. ред.) Русский семантический словарь. Толковый словарь, систематизированный по классам слов и значений. Москва: Азбуковник, 1998. Режим доступа: http://www.slovari.ru/search.aspx?s=0\&p=3068 (202004-20).

Gebauer, J. Slovnik staročeský. Praha, 1916. Режим доступа: https://vokabular.ujc.cas.cz/hledani.aspx?hw=d\%u00e9ka (2020-04-20).

Kott, F. Š. Česko-německý slovník. Praha, 1878-1893. Режим доступа: http://kott.ujc.cas.cz/index.php?vstup=lelek\&hledat=fulltext\&heslo=checked\& Zvyraznit $=\&$ Vyber $=\& Z$ Zobrazeni $=\&$ Strana $=\&$ stranaVys $=1^{~}$ (2020-04-20).

Machek, V. Etymologický slovnik jazyka českého a slovenského. Praha: Nakladatelství ČSAV, 1957. Режим доступа: https://books.google.ru/books/about/ Etymologick\%C3\%BD_slovn\%C3\%ADk_jazyka_\%C4\%8Desk\%C3\%A9ho.ht ml?id=h_ICAAAAMAAJ\&redir_esc $=y(2020-04-20)$.

Slovník slovenského jazyka. Bratislava: Vydavatel'stvo SAV, 1959-1968. Режим доступа: https://slovnik.juls.savba.sk/ (2020-04-20).

Słownik języka polskiego. Warszawa, 1900. Режим доступа: https://polski.pro/slownikjezyka-polskiego-karlowicz-j-krynski-aniedzwiedzki-w-t-1-8-1900-1927/ (2020-04-20). 
Stownik staropolski. Warszawa: PAN, 1953. Режим доступа: https://pjs.ijp.pan.pl/ sstp.html (2020-04-20). (c) $\left(\begin{array}{l}\text { The article is accessible in open access mode under licence CC BY-NC-ND } \\ \text { Creative Commons Attribution-NonCommercial-NoDerivatives } 4.0\end{array}\right.$ 